\title{
New records, synonymy and description of the male of Culicoides horticola Lutz, 1913 (Diptera: Ceratopogonidae)
}

\author{
Maria Luiza Felippe-Bauer ${ }^{1,3} \&$ Gustavo Ricardo Spinelli ${ }^{2}$ \\ ${ }^{1}$ Laboratório de Diptera, Instituto Oswaldo Cruz, \\ Fundação, Oswaldo Cruz - Fiocruz, \\ Av. Brasil, 4365, CEP 21045-900, Rio de Janeiro, RJ, Brasil \\ ${ }^{2}$ Divisão de Entomologia, Museu de La Plata, La Plata, Argentina \\ ${ }^{3}$ Corresponding author: Maria Luiza Felippe-Bauer, e-mail: mlfbauer@ioc.fiocruz.br
}

FELIPPE-BAUER, M.L. \& SPINELLI, G.R. 2009. New records, synonymy and description of the male of Culicoides horticola Lutz, 1913 (Diptera: Ceratopogonidae). Biota Neotrop. 9(1): http://www.biotaneotropica. org.br/v9n1/en/abstract?article+bn00309012009.

Abstract: The male of Culicoides horticola Lutz, 1913 is described and illustrated from specimens collected in the Department of Madre de Dios, Peru, and in the State of Rio de Janeiro, Brazil. Culicoides bachmanni Spinelli, 2005 is considered as a junior synonym of $C$. horticola. Previous citations and descriptions of $C$. horticola are discussed, and the species is firstly recorded from Peru and biting humans.

Keywords: Culicoides horticola, male, Culicoides bachmanni, synonymy, new records.

FELIPPE-BAUER, M.L. \& SPINELLI, G.R. 2009. Novos registros, sinonímia e descrição do macho de Culicoides horticola Lutz, 1913 (Diptera: Ceratopogonidae). Biota Neotrop. 9(1): http://www.biotaneotropica. org.br/v9n1/pt/abstract?article+bn00309012009.

Resumo: O macho de Culicoides horticola Lutz, 1913 é descrito e ilustrado com base em espécimes coletados no departamento de Madre de Dios, Peru, e no estado do Rio de Janeiro, Brasil. Culicoides bachmanni Spinelli, 2005 é considerada como sinônimo júnior de $C$. horticola. Citações e descrições anteriores de $C$. horticola são discutidas e a espécie é reportada pela primeira vez para o Peru e picando humanos.

Palavras-chave: Culicoides horticola, macho, Culicoides bachmanni, sinonímia, novos registros. 


\section{Introduction}

Lutz (1913) described Culicoides horticola from female specimens from Tatuí ("Tatuhy”), São Paulo, Brazil, including an excellent illustration of the female wing. Costa Lima (1937) illustrated the palpus of this species based on a specimen belonging to Lutz's type-series. Forattini (1957) examined one female and one male from Batea, São Paulo state, and described the male of $C$. horticola from this material; he also considered $C$. imitator Ortiz, 1953 as a junior synonym of $C$. horticola, but this assumption was not accepted by Wirth \& Blanton (1959), Wirth et al. (1988), Borkent \& Wirth (1997), and Borkent \& Spinelli (2000, 2007). Subsequent authors included C. horticola in several identification keys (Spinelli \& Wirth 1986, Ronderos \& Spinelli 1998, 2002, Spinelli et al. 2005). In the last mentioned paper, the authors compared $C$. horticola with a new described species, C. bachmanni Spinelli 2005.

The study of the specimens described by Forattini (1957) as C. horticola showed that they were misidentified, and therefore the male of this species remains undescribed. Besides, the examination of the type-series of $C$. horticola, as well as the study of similar specimens from Argentina, Paraguay and Peru revealed that C. bachmanni is a junior synonym of $C$. horticola. The purpose of this paper is to describe and illustrate the male of $C$. horticola, to discuss the above referred synonymy, and to provide new records of this species from Peru.

\section{Material and Methods}

The male described herein are slide-mounted in phenol-balsam in the manner described by Wirth \& Marston (1968). Voucher specimens are deposited in the Ceratopogonidae collection of the Diptera Laboratory of the Instituto Oswaldo Cruz, Rio de Janeiro, Brazil (IOC). In addition to IOC, the collections of the Faculdade de Saúde Pública, Universidade de São Paulo, Brazil (USP) and the Museo de La Plata, Argentina (MLP) were revised during this study. A detailed description of the female of $C$. horticola may be found in the description of C. bachmanni in Spinelli et al. (2005). Terms for structures follow MacAlpine et al. (1981).

\section{Results}

\section{Culicoides horticola Lutz, 1913 (Figures 1-4)}

Culicoides horticola Lutz, 1913:61 (female; Brazil; fig. wing); Costa Lima, 1937:32 (fig. palpus erroneous); Forattini, 1957:318 (misident., syn. imitator; redescript.; figs. eye separation, palpus, thorax, wing; figs. flagellomeres 8-9 and male genitalia erroneous); Spinelli \& Wirth, 1986:61 (in key; wing photo); Ronderos \& Spinelli, 1990:84 (in part., specimens from Buenos Aires province, Argentina); Borkent \& Wirth, 1997:70 (in catalog); Ronderos \& Spinelli, 1998:81 (records for Yacyreta dam Lake area); Borkent \& Spinelli, 2000:32 (in catalog); Felippe-Bauer \& Oliveira, 2001:1113 (in type list; misident., in part.); Silva et al., 2001:353 (records for Rio de Janeiro, Brazil); Borkent \& Spinelli, 2007:67 (in catalog).

Culicoides bachmanni Spinelli, 2005:146 (female; figs. antenna, palpus, spermathecae, wing photo; records for Misiones, Argentina and Itapuã, Paraguay).

Female diagnosis: A small-sized species (wing length $0.64-0.78 \mathrm{~mm}$ ) of the subgenus Haematomyiidium, distinguished by the following combination of characters: eyes pubescent, narrowly separated; antennal sensillar pattern 1, 6-8; AR 0.52-0.64; flagellomeres 9-10 clearly shorter than preceding and following ones; third palpal segment moderately large with shallow pit; PR 1.40-1.95; P/H ratio 0.56-0.60; mandible with $12-13$ teeth; poststigmatic pale spots in cell $r_{3}$ fused, longitudinally aligned; distal pale spot in cell $\mathrm{r}_{3}$ rounded not abutting wing margin; $\mathrm{CR}$ 0.53-0.58; macrotrichia sparse on distal fourth of wing; halter pale; two ovoid, subequal spermathecae.

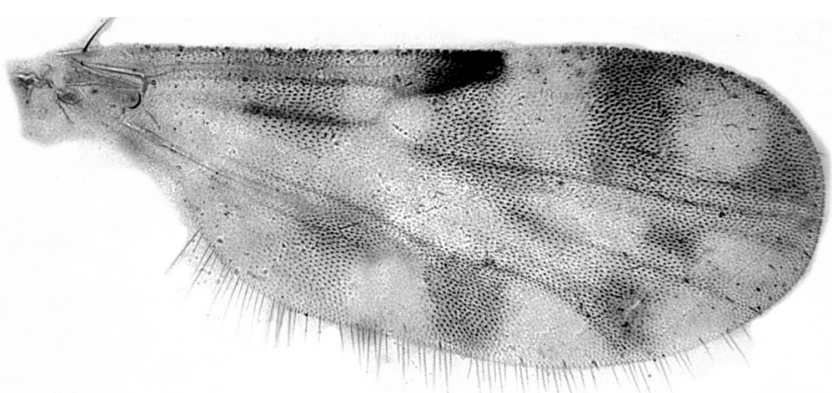

Figure 1. Culicoides horticola Lutz, 1913, male wing photograph.

Figura 1. Culicoides horticola Lutz, 1913, fotografia da asa do macho.
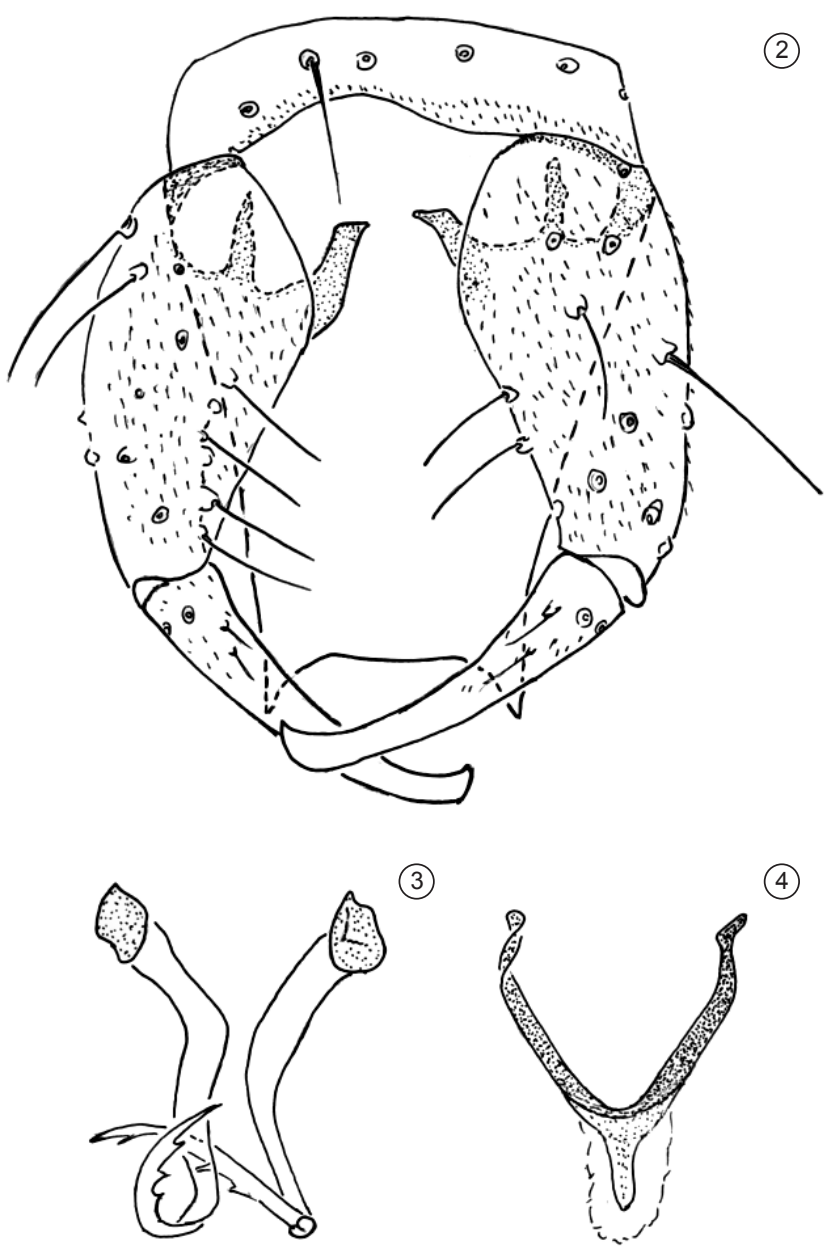

(4)

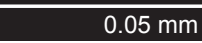

Figures 2-4. Culicoides horticola Lutz, 1913, male. 2. terminalia (aedeagus and parameres removed). 3. parameres. 4 . aedeagus.

Figuras 2-4. Culicoides horticola Lutz, 1913, macho. 2. terminália (edeago e parâmeros removidos). 3. parâmeros. 4. edeago. 
Male: Similar to female with usual sexual differences. Wing length $0.59 \mathrm{~mm}$, breadth $0.26(\mathrm{n}=2) \mathrm{mm}$, costal ratio $0.51-0.53$ $(0.52, n=2)$, pattern as in Figure 1. Terminalia (Figure 2): tergite 9 tapering, produced beyond gonoxites, with short, subparallel, apicolateral processes, posteromedial margin without lobe or cleft; sternite 9 with shallow posteromedial excavation. Gonocoxite twice as long as broad, ventral root stout without hell-like expansion, dorsal root elongate, slender; gonostylus tapering distally, distal portion slightly curved. Parameres (Figure 3) separate, each with strongly sclerotized knob; posteromedial projection slender, bent near base, slightly sinuate on midportion, without ventral lobe; distal portion tapering, abruptly bent, ventromesally directed, with lateral fringe of fine spicules. Aedeagus (Figure 4) with basal arch extending to half of total length; basal arms moderately stout; distal portion slender, single, with rounded apex, encircled by hyaline membrane.

Specimens examined: ARGENTINA, Misiones prov., Corpus, 23.X.2003, A. Giménez, CDC light trap (holotype of C. bachmanni, MLP); same data except 10.IV.2002, G. Spinelli, 1 female (MLP); Posadas, Mártires stream, 14.VI.1994, G. Spinelli, CDC light trap, 1 female (MLP); 9 de Julio, 11.XI.2003, A. Giménez, CDC light trap, 1 female (MLP); Buenos Aires prov., Punta Lara, 25.XI.1985, G. Spinelli-M. Ronderos, CDC light trap, 3 females (MLP).

BRASIL, São Paulo, Tatuhy, Costa Lima prep., V.1937 (\#3242-3243, IOC, Lutz's type series n. 2405.); Tatuhy (em pomar), I.1903, 1 male (E. 1057, USP), 1 female (E. 1058, USP); Rio de Janeiro, Campos dos Goytacazes, Turfe, 21.IX.1989, FEEMA col., NewJersey, 1 male, 2 females; same data except 04.VII.1989, 5 females; same data except 15.X.1989, 1 female.

PARAGUAY, Itapuã, Encarnación, Santa Maria stream, 18.X.1993, H. Ferreyra, CDC light trap, 1 female (MLP); Mayor Otaño, 11.IV.1994, G. Spinelli, CDC light trap, 1 female (MLP).

PERU, Amazonas, Utcubamba prov., Cajaruro distr., San Antonio - El Ron, 10.XI.2001, 3 females, biting human; same data except 08.XII.2001, 2 females; Madre de Dios, Tombopata prov., Laberinto distr., Santa Rosa, 7/8.VIII.2002, CDC light trap, 1 male.

Distribution: Argentina (Misiones, Buenos Aires provinces), Brazil (Rio de Janeiro, São Paulo), Paraguay (Itapuã), Peru (Amazonas, Madre de Dios).

\section{Taxonomic Discussion}

Analyzing specimens from Tatuí (\#1057-1058) and Batea (\#12225-12226) studied by Forattini we observed clear differences between them. The female from Tatuí has pubescent eyes, while the eyes of the female from Batea are bare. Also, the later is a larger species, and the poststigmatic pale spots are separated and not aligned one behind the other, as it is typical of $C$. horticola. For these reasons, we consider that only the specimens from Tatuí, the species type-locality, belong to C. horticola and that Forattini (1957) misidentified $C$. horticola. Therefore, his description of the male is based on another species of Culicoides.

Four slides deposited in the Ceratopogonidae Collection of the Diptera Laboratory at the Instituto Oswaldo Cruz (IOC), were considered as the type-series of $C$. horticola by Felippe-Bauer and Oliveira (2001) due to the indication in the slides of the term "cotype" by Willis Wirth handwriting. Two of these slides (\#3242, 3243), which are signaled "Tatuí, São Paulo", only include the wings, and the other two $(\# 2815,2816)$, without any indication of the site of capture, include wing and female body, respectively. Felippe-Bauer
\& Oliveira (2001) mentioned that these last cited slides belong to one specimen. Our observation of the specimen mounted in the slides 2815 and 2816 revealed that it does not present the pale wing pattern as described for $C$. horticola by Lutz (1913). This fact suggests that only the slides 3242 and 3243 containing the wings identical to the one illustrated in the original description, belong to C. horticola and should be considered as Lutz's type material.

The Ceratopogonidae Collection of IOC also houses one slide (\#3244) containing five females from Sophia, São Paulo state, identified as $C$. horticola by Angelo da Costa Lima. Most probably Costa Lima (1937) illustrated the palpus of $C$. horticola based on these specimens. Our study of this material revealed that they belong to two different species, both with the poststigmatic pale spots not fused and aligned, and with the flagellomeres 9 and 10 similar in lenght to the precedings and posteriors ones. Because of this, we conclude that they do not belong to C. horticola, and that Costa Lima (1937) illustrated the palpus from another species.

Spinelli et al. (2005) described C. bachmanni based on female specimens from Argentina and Paraguay. The authors pointed out that the wing pattern of the new species and the one of $C$. horticola are identical, but $C$. bachmanni may be distinguished by the flagellomeres 9 and 10 clearly smaller than the preceding and following ones. They considered that the flagellum of $C$. horticola corresponds to the one illustrated by Forattini (1957), which shows the flagellomeres 9 and 10 with the same length as the preceding and following ones. While studying specimens of both sexes from the Departments of Amazonas and Madre de Dios in Peru, and specimens from Brazil (Campos dos Goytacazes, Rio de Janeiro state) determined by Silva et al. (2001) as C. horticola, as well as specimens from the typelocality, we observed that the females have the same wing pattern as $C$. horticola and small flagellomeres 9 and 10. Therefore, we herein conclude that $C$. bachmanni should be considered as a junior synonym of $C$. horticola. Furthermore, the specimens considered as C. horticola by Spinelli et al. (2005) belong to a new species, which will eventually be described after the collection of the male.

This is the first record of C. horticola from Peru, and also the first mention of this species biting humans.

\section{Acknowledgements}

To our colleague Maria Anice Sallum, for the loan of the male and female specimens of $C$. horticola from Batea and Tatuí deposited in the Entomological collection of the Faculdade de Saúde Pública, Universidade de São Paulo. To Abraham G. Caceres, for sending the specimens from Peru for analysis. To Rodrigo Mexas and Bruno Eschenazi, for assistance in the wing photographs and illustrations. To Sara Montemayor, for valuable suggestions on the early version of the manuscript.

\section{References}

BORKENT, A. \& SPINELLI, G.R. 2000. Catalog of the new world biting midges south of the United States of America (Diptera:Ceratopogonidae). Contrib. Entomol. Int. 4(1): 1-107.

BORKENT, A. \& SPINELLI, G.R. 2007. Neotropical Ceratopogonidae (Diptera: Insecta). In: Adis, J., Arias, J.R., Rueda-Delgado, G. \& Wantzen K.M. (Eds.). Aquatic biodiversity in Latin America. Pensoft, Sofia-Moscow, $198 \mathrm{p}$.

BORKENT, A. \& WIRTH, W.W. 1997. World species of biting midges (Diptera:Ceratopogonidae). Bull. Am. Mus. Nat. Hist. 233: 1-257.

COSTA LIMA, A. 1937. Chave das especies de Culicoides da região neotrópica (Diptera: Ceratopogonidae). Mem. Inst. Oswaldo Cruz 32(3): 411-422. 
Felippe-Bauer, M.L. \& Spinelli, G.R.

FELIPPE-BAUER, M.L. \& OLIVEIRA, S.J. 2001. Lista dos exemplares tipos de Ceratopogonidae (Diptera, Nematocera) depositados na Coleção Entomológica do Instituto Oswaldo Cruz, Rio de Janeiro, Brasil. Mem. Inst. Oswaldo Cruz 96(8): 1109-1119.

FORATTINI, O.P. 1957. Culicoides da Região Neotropical (Diptera:Ceratopogonidae). Arq. Fac. Hig. Saude Publica Univ. São Paulo 11(2): 159-526.

LUTZ, A. 1913. Contribuição para o estudo das ceratopogoninas hematófagas do Brasil. Mem. Inst. Oswaldo Cruz 5(1): 45-72.

MACALPINE, J.F., PETERSON, B.V., SHEWELL, G.E., TESKEY, H.J., VOCKEROTH, J.R. \& WOOD, D.M. (Eds.). 1981. Manual of Nearctic Diptera. Monograph 27, Agriculture Canada, 674 p.

RONDEROS, M.M. \& SPINELLI, G.R. 1990. Further notes on Culicoides Latreille 1809 from Argentina (Insecta, Diptera, Ceratopogonidae). Iheringia, Sér Zool 70: 81-88.

RONDEROS, M.M. \& SPINELLI, G.R. 1998. Las espécies de Culicoides en el area de influencia de la represa de Yacyreta (Diptera: Ceretopogonidae). Rev. Soc. Entomol. Argent. 57(1-4): 79-83.

RONDEROS, M.M. \& SPINELLI, G.R. 2002. Los Culicoides de la Argentina: clave de especies y nuevos registros (Diptera: Ceratopogonidae). In: D. Salomón (Comp.). Actualizaciones en Artropodología Sanitaria Argentina. Serie Enfermedades Transmisibles, Pub. Monogr. $\mathrm{N}^{\circ} 2$. Fundación Mundo Sano, Buenos Aires, p. 89-95.
SILVA, C.S., FELIPPE-BAUER, M.L., ALMEIDA, E.H.G. \& FIGUEIREDO, L.R. 2001. Culicoides (Diptera: Ceratopogonidae) do estado do Rio de Janeiro, Brasil. I. Região Norte: Município de Campos do Goytacazes. Entomol. Vect. 8(3): 349-358.

SPINELLI, G.R. \& WIRTH, W.W. 1986. Clave para la identificacion de las especies del género Culicoides Latreille presentes al sur de la cuenca amazonica. Nuevas citas y notas sinonimicas (Diptera: Ceratopogonidae). Rev. Soc. Entomol. Argent. 44(1): 49-73.

SPINELLI, G.R., RONDEROS, M.M., DÍAZ, F. \& MARINO, P.I. 2005. The bloodsucking biting midges of Argentina (Diptera: Ceratopogonidae). Mem. Inst. Oswaldo Cruz 100(2): 137-150.

WIRTH, W.W. \& BLANTON, F.S. 1959. Biting midges of the genus Culicoides from Panama (Diptera: Heleidae). Proc. U.S. Nat. Mus. 109(3415): 237-482.

WIRTH, W.W. \& MARSTON, N. 1968. A method for mounting small insects on microscope slides in Canada Balsam. Ann. Entomol. Soc. Am. 61(3): 783-784.

WIRTH, W.W., DYCE, A.L. \& SPINELLI, G.R. 1988. An Atlas of wing photographs, with a summary of the numerical characters of the neotropical species of Culicoides (Diptera:Ceratopogonidae). Contr. Am. Entomol. Inst. 25(1): 1-72. 